\title{
SPECIAL INSTITUTES OF THE KANUN OF LEKË DUKAGJINI AND ITS APPLICATION IN CONTEMPORARY TIME AMONG THE ALBANIANS
}

Doc. dr. sc. Islam Qerimi*

\author{
UDK: 34(496.5)-05 Dukagjini, L. \\ https://doi.org/10.30925/zpfsr.41.2.8 \\ Ur.: 25. svibnja 2019. \\ Pr.: 11. prosinca 2019. \\ Pregledni rad
}

\begin{abstract}
Summary
The purpose of this article is to discuss the application of some special institutes of Kanun of Lekë Dukagjini in contemporary law of Albanians. Traditionally, this kanun has had and still remains to have impact in all fields of the life of Albanians. In other words, the application of this kanun still challenge the modern legal system as a consequence that people continue to solve their misunderstandings based on this kanun. Through this article is aimed to be made clear the written customary law and to be pointed out the advantages and disadvantages of its application and the connection with some rules of public (criminal) law and private (civil) law.
\end{abstract}

Key words: customary law; Kanun of Lekë Dukagjini; contemporary law; Kosovo law.

\section{THE CONTEMPORARY APPLICATION OF THE KANUN (INTRODUCTION)}

The Kanun of Lekë Dukagjini ${ }^{1}$ (hereafter: KLD) is one of the most famous act of customary law in Albanian territories and beyond. It is undeniable that among Albanians, traditional relations continued at a higher intensity than in other ethnic groups in the Balkans. ${ }^{2}$ According to studies ${ }^{3}$ at Albanian universities regarding the

* Islam Qerimi, Ph.D., Assistant Professor, University of Mitrovica "Isa Boletini”, Faculty of Law; islam.qerimi@umib.net.

1 Shtjefën Gjeçovi, Kanuni i Lekë Dukagjinit, Shkoder: CreateSpace Independent Publishing Platform, 2014.

2 Colin W. Lawson, Douglas K. Saltmarshe, "The Psychology of Economic Transformation: The Impact of the Market on Social Institutions, Status and Values in a Northern Albanian Village", Journal of Economic Psycholgy, vol. 23/4, (2002), 487-500.

3 Natalja Qana, Qasje Socialo-Historike e Fenomenit të Gjakmarrjes dhe Pasojave të tij mbi Gratë dhe Fëmijët (dissertation). University of Tirana, The Institute of International Studies, 2016, 90; Mariglena Gjoni, Ndikimi i dFenomenit të Gjakmarrjes në Vetëkonceptin e Fëmijëve të Moshës 7-15 vjeç (dissertation). University of Tirana, The Department of Psychology- 
reasons why old Kanun elements emerged, it was concluded that attention needs to be paid to communities that moved away from territories where customary law was heavily applied. According to this data, these communities believed in a life codified according to the Kanun, which sets out moral values. They are now seeking a different identity. Due to a failure to integrate, a part of these communities are considering to return to their places of birth, yet are meeting difficulties due to damaged or sold homes. Thus, these dissertations rightfully claim that it is not that Kanun that is experiencing a crisis, but a civil society that cannot achieve organizing itself according to new European standards. Youth and adults are taking steps towards modernization, while also not putting aside the mentality of the Kanun, taking with its positive values.

According to scientific data, norms of the Kanun are being skewed and confused nowadays, causing not only men and boys over the age of 15 to isolate themselves to avoid blood feuds, but also women, girls and children. ${ }^{4}$ In 2014, 84 children under the age of 16 were isolated only in the Region of Shkodra (in Albanian: Shkodër), most of whom were born in to isolation. ${ }^{5}$ Blood feuds caused the deaths of 15 -year-old and 12-year-old children in the beginning of the $211^{\text {st }}$ century. ${ }^{6}$ Concerns brought about by the phenomenon of blood feuds were mentioned in the European Commission Progress Report for Albania in 2014. According the 2015 report, blood feuds, as an archaic institution of the Albanian Kanun, were considered to still pose a problem in Albania, but at a more limited scale. ${ }^{7}$ In the 2016 report, blood feuds were still considered evident in Albania and the reactivation of the Coordinating Council for the issue of blood feuds, which was recommended by the European Commission in the 2015 report. $^{8}$

The Assembly of the Republic of Albania approved a resolution in March $2015^{9}$ for the prevention of blood feud killings in Albania. This resolution requests the government to seriously evaluate the phenomenon of blood feuds, to strengthen cooperation with public administration institutions and coordinate with NGOs in order to stop killings. The Albanian authorities were requested to strengthen cooperation

Pedagogy, Faculty of Social Sciences 2016.

4 Lulzim Lelçaj, Zef Mila, Rajmonda Kçira, Konfliktet dhe Zgjidhja e Tyre: Material Shpjegues dhe Orientues: Conflicts and their Resolution: An Explanatory, Orienting Material”, Shkoder: Qendra "Drejtesi dhe paqe", 2001, 39.

5 Mentor Kikia, The leader of the organization Free Thought Forum. Interview for Radio Europa e Lirë (14.01.2014.)

6 Emin Spahia, Të Zhdukim Ngujimin Kolektiv dhe të Respektojmë Shtetin Ligjor, We should Strike Out the Collective Fastening and Respect the Legal State, Ligji dhe Jeta, UNFPA 2003, 39.

7 Komisioni Evropian. Dokument Pune i Stafit të Komisionit - Raporti i Vitit 2015 për Shqipërinë, 10.11.2015, Bruksel: Komisioni Evropian, DPS 2015: 213, 57. Accesable on 13. July 2019 https://amf.gov.al/files2/File/Komisioni\%20Evropian,\%20raporti\%20i\%20vitit\%202015\%20 per\%20Shqiperine.pdf.

8 European Commission, Commission Staff Working Document Albania 2016 Report, Brussels: European Commission 9.11.2016 SWD 364 final: 63. Accesable on 13. July 2019. https:// ec.europa.eu/neighbourhoodenlargement/sites/near/files/pdf/key_documents/2016/20161109_ report_albania.pdf

9 Fletorja Zyrtare e Republikës së Shqipërisë, 2015, nr. 38. Tiranë: Botim i Qendrës së Botimeve Zyrtare, 2015. 
with foreign countries and Interpol in order to extradite individuals who are wanted or sentenced by Albanian courts for crimes related to blood feuds or revenge killings. It is important to note that European Commission progress reports on Kosovo do not mention blood feuds as evident, instead it was requested to combat money laundering, funding of terrorism, organized crime and corruption as well as changing laws and procedures in order to fight these phenomena and some other issues regarding investigative procedures. ${ }^{10}$

\section{THE STRUCTURE OF THE KANUN}

The version of the KLD codified by Shtjefën Gjeçovi consists of 12 books and is divided into 24 chapters, 159 subchapters and has 1263 articles. The books are as the following:

- Book I: The Church;

- Book II: The Family;

- Book III: Marriage;

- Book IV: House, Livestock and Property;

- Book V: Work;

- Book VI: Transfer of Property;

- Book VII: The Given Word;

- Book VIII: Honor;

- Book IX: Damages;

- Book X: The Law Regarding Crimes;

- Book XI: Judicial Body (pleqnia); and

- Book XII: Exemptions and Exceptions.

In the following part of the paper, the positive and negative aspects of the Albanian customary law principles will be dissected. The KLD shares most similarities with Justinian's Code (534). Justinian I, who was of Dardanian/Illyrian ancestry, was born in Tauresium near modern-day Skopje. Both codes contain 12 books. The order and substance of their order of books, laws, articles and paragraphs are very similar. Justinian's Codex had 1600 paragraphs, while the KLD has 1263. An important difference in the first book of Justinian's Code as compared to the KLD is that the church is excluded from the right of political power.

\section{MEETINGS OF THE KANUN ASSEMBLY}

Kanun and assembly is the basis of the Albanian customary law The assembly was considered to be the highest court in society. The most influential assemblies were those of odas (spaces where men convene) and kullas (traditional Albanian houses). Clans would convene in these locations in order to solve issues or make truces (Article 1106 of the KLD). The most important houses were located in Dukagjin, Kelmend,

10 Komisioni Evropian, Dokument Pune i Personelit të Komisionit Raport për Kosovën. 2018, Strasburg: Komisioni Evropian, 17.4.2018 SWD (2018) 156 final 17.4.2018.), 29. Accesable on 13. July 2019. https://www.m-ks.net/repository/docs/kosovo_report_2018_shqip.pdf 
Orosh, Kurbin, Martanesh, Puka, Gjakova, etc. The leading households were those of Chieftain, Bajrak, Head Elder, etc. An important characteristic was that men in these assemblies were not allowed to offend or insult anybody (Articles 1123 and 1124 of the KLD). Only in the assemblies of the five bajraks (Albanian territorial unit under the Ottoman Empire) of Shën Pal was it allowed to deliver capital punishment. ${ }^{11}$ General assemblies also existed, where participation was defined as "one man per house" and they were organized either by the flag-bearer or chieftain of Mirdita. The opening remarks were always very formal and uttered with the formula: "The Bajrak is gathered to deal with specific issues such as..., as God and the Kanun require." 12 If any participant fired a gun during the assembly, he would be killed immediately. Then, the assembly would stop and the former's house and livestock would be burned. ${ }^{13}$

\section{POSITIVE AND NEGATIVE ASPECTS OF THE KANUN}

The KLD is composed by different rules which are considered to have positive or negative aspects. Positive aspects or principles of the KLD are considered to be as the following: ( $i$ ) the truce - the given word (besa); (ii) hospitality (iii) manhood (burrëria); (iv) honor (nderi), and (v) protection (mbrojtja). By contrary, negative aspects are considered to be: (i) blood vengeance (gjakmarrja); (ii) gender inequality (pabarazia e gjinisë); (iii) the right to marriage (e drejta për martesë); (iv) the exclusion of women from the right to inheritance (përjashtimi i gruas nga trashëgimia).

\subsection{Positive aspects}

\subsubsection{The truce (the given word)}

One of the first and most positive sui generis institutions that caracterizes the Albanian customary law is the truce (in Albanian: besa). Professor Syrja Pupovci dubbed it "a sacred institution"14 of the Albanian customary law. For Albanians, the truce means: word of honor, faithfulness, reconciliation, promise, pact, tract, armistice. In the KLD, the truce is dealt with in Articles 854-885. In Article 854, the truce is defined as: "a period of freedom and security which the family of the victim gives to the murderer and his family, temporarily suspending pursuit of vengeance in the blood feud until the end of the specified term." In case the family of the perpetrator received a truce from the family of the victim, they would enjoy a physical security of 24 hours in order to attend the burial of the victim, as well as the wake (Article 856 of the KLD). After the first truce, a request could be made to extend it for another 30 days. Only the village could request this truce (Articles 858 and 859 of the KLD).

It is important to underline the fact that mediators that achieve the truce are not entitled to payment by either party (Article 853 of the KLD). The truce would be

11 Walther Peinsipp, Populli i Shqipeve të Malit, Tiranë: Shtëpia botuese "Mirdita”, 2005, 75.

12 Peinsipp, Populli i Shqipeve të Malit, 78.

13 Peinsipp, Populli i Shqipeve të Malit, 79.

14 Syrja Pupovci, Marrëdheniet Juridike - Civile në Kanunin e Lekë Dukagjinit, Prishtinë: Enti TMM, 1971, 213. 
applied in agreements of armistice and served as a tool to reconcile parties (families, clans or Bajraks) in blood feud conflicts. The party that would violate this institution would be held accountable before the Council of the Elders. Violation of the truce would be sanctioned by capital punishment on the KLD. According to Article 648: "A traitor who betrays someone himself or sells out someone who has given him his trust is destroyed by the village and his blood goes unavenged. "Writer Sami Frashëri said about the truce that: "The truce given by an Albanian is not denied, broken, but kept until the final heartbeat". ${ }^{15}$ Ismajli rightfully stated that the institution of the truce differentiated the Albanian customary law from other customary laws. ${ }^{16}$ The institution of the truce is known among the Bulgarians and Romanians as besa, the Albanian word for the truce, and among Southern Slavs as arbanaška vera (what Albanians believe). ${ }^{17}$ Besa was also invoked in cases when there was fighting between opponents. If the enemies were given a truce by Albanians and they lost, they would have the possibility of withdrawing safely and would not be in danger. ${ }^{18}$

\subsubsection{Hospitality}

According to the Albanian customary law, a guest was considered someone known or unknown, invited or uninvited, relative or otherwise, a local or a foreigner, a man or a woman of any age who went to an Albanian's house to seek shelter or protection, to visit relatives, or to make agreements. Article 602 of the KLD writes: "The house of the Albanian belongs to God and the guest." Hospitality (in Albanian: mikpritja) is considered an important and sacred principle in the Albanian customary law, and is known in all Albanian kanuns. Based on written accounts, Albanian hospitality has its roots in the Illyrian culture. ${ }^{19}$ Among the most important principles related to hospitality are: "The guest must be honored with bread and salt and the heart" (Article 608 KLD) and "Every guest must be given the food eaten in the house" (Article 611 KLD).

According to the Albanian customary law, the host was considered a poor, generous man, who would offer the guest food from his wife's, children's and his own share, and rather let his house be extinguished rather than break a guest's protection. ${ }^{20}$ Hospitality among Albanians would also be offered to enemies. There are known cases where opponents of Albanians utilized this institution of the KLD and requested hospitality of Albanians. Since hospitality was considered sacred by the host, this would lead to blood wars between Albanians. ${ }^{21}$ It is important to mention the

15 Sami Frashëri, Shqipëria ç'ka qenë, ç'është $e$ ç'do të bëhet, (Prishtinë: Dija, 2007.), 90.

16 Hilmi Ismajli, Besa në të Drejtën Zakonore Shqiptare, Gjurmime Albanologjike Nr. 1, (Prishtinë: Instituti Albanologjik i Prishtines, 1971), 92.

17 Genc Myftiu, Albania a Patrimony of European Values: A Short Encyclopedia of Albanian History and Cultural Heritage, (Tirane: SEDA Agency: FILD Foundation, 2000), 156.

18 Noel Malcolm, Kosovo a Short History, (New York: University Press, 1999), 24, 232, 277.

19 Ekrem, Çabej, "Zakone dhe Doke të Shqiptarëve”, in: Studime Shqiptare vëll. V, (Prishtinë: Rilindja, 1976), 199.

20 Ernest Koliqi, E Drejta e Kanunit Shqiptar dhe e Drejta Romake, in: Studime e Tekste Juridike, Nr. I, (Romë: Botim i Insitutit të Studimeve Shqiptare, (1944).

21 Serge R. Doucette and Hamdi Thaqi, Kosova "Demokraci Morale" apo Kosova "Serbi e 
similarities between hospitality in the Albanian customary law and in ancient Japanese tradition. Hospitality was considered magical by ancient Japanese communities. They believed that the gods would visit their villages twice a year, masked as guests in order to mix with the villagers, and convey blessings through conversation. In exchange for this, the guest would give blessings, spoken words that were believed to be magical, which gave happiness and well-being to the family of the host for the whole year. ${ }^{22}$ One difference between the KLD and the Kanun of Dagestan is that the betrayal of the guest could not be forgiven in the former, whereas in the latter it was regulated through fines and payments, be it property or money. ${ }^{23}$ In Islamic law, hospitality was also considered a type of generosity. In Surahs 51:25-28, information is given on greeting with peace among people who do not know each other. ${ }^{24}$

\subsubsection{Manhood}

To be considered a man - adult (in Albanian: burrëria) according the KLD, one had to fulfill a set of general conditions. The first condition was that a man could only be born of a highlander father (subchapter 148), and the second was that a boy had to be 15 years of age in order to carry a gun (Article 95 of the KLD). After reaching that age, the boy would be greeted with: Are you a man, how are you and the answer would be: May we have you with honor ${ }^{25}$ According to the Albanian customary law, mashkull (male) and burrë (man, where burrëri - manhood derives) were different because a mashkull was not necessarily a burrë. A man would be characterized by his wits, honor, hospitality, perseverance, undoubtedness and sacrifice for the country in war and peace. ${ }^{26} \mathrm{~A}$ man would also not speak a lot, but would convince people with few but mature words. In the Albanian family, the man enjoyed all rights and property. ${ }^{27}$ The first man would be considered the leader of the family. This person is analogous to the patria potestas in Roman law (the power of the father over all other family members), pater familias (power over property and family members), and sui juris (independent). Further, a man was required to attend assemblies.

\subsubsection{Honor}

Personal honor and dignity were considered as the highest social values in the

Madhe", (Prishtinë: Europrinty, 2004), 263.

22 Shinobu, Origuchi. Zenshu. Obras Completas de Origuchi Shinobu, Vol. 1, Tokyo: Chüo Koronsha, (1954), 3-62.

23 Muharrem Dragovaja, Studim Krahasues i Kanunit te Shqipërise dhe Dagestanit, (Tiranë: University of Wisconsin-Madison, 1996), 4.

24 Sherif H. Ahmeti, Kur'an-i - Përkthim me Komentim në Gjuhen Shqipe (Prishtinë: Kryesia e Bashkësisë Islame për RS të Serbisë, 1988), 602.

25 Kahreman Ulqini, Struktura Shoqërisë Tradicionale Shqiptare, (Shkodër: "Idromeno", 2003), 107.

26 Ulqini, Struktura Shoqërisë Tradicionale Shqiptare, 106-107.

27 Margaret Hasluck, Kanuni Shqiptar: Ligji i Pashkruar Shqiptar, translated from English by Leka Ndoja, (Lisitan: 2005), 36. (Orig. Margaret Masson Hardie Hasluck, The Unwritten Law in Albania (Cambridge: University Press, 1954). 
KLD. ${ }^{28}$ Article 597 of the KLD writes: "There is no fine for an offense to honor. An offense to honor is never forgiven" and Article 600 writes: "A man who has been dishonored is considered dead to the Kanun." There were two types of honor (in Albanian: nderi) in the KLD: (i) personal and (ii) familial. Thus, an individual was responsible not only for protecting his own honor, but also the honor of his family and clan as pater familias. According to the KLD, an Albanian lives for "two fingers of honor" and "two fingers of honor and a clear conscience". Further, there is stated that "An offense to honor is not paid for with property, but by the spilling of blood or by a magnanimous pardon (through the mediation of good friends)." (Article 598 of the KLD).

According the Albanian customary law, the principles of "may God not disgrace us" and "better ruined than disgraced" were applied. A man whose honor was infringed upon de facto did not have the authority to act until he set his honor right. Honor could be infringed upon in these cases: ${ }^{29}$

- if a man was kicked, hit with a stick, shoved or any other type of touching with hands,

- if a family member broke the trust of the guest or protection,

- being insulted (saying that he is lying in an assembly or other denigrating statements),

- surrendering to the enemy or being disarmed by somebody,

- if your corpse is left with the enemy.

It is important to mention the fact that the KLD explicitly regulated the honor of women. Article 95 stipulated that: "The life and honor of a woman is guaranteed by the Kanun." It is worth mentioning that the institution of honor in Islamic law, which was applied in occupied Albanian territories, and honor in the Albanian customary law. While in Islamic law (Surah 5:32 of the Quran) ${ }^{30}$ nobody has the right of depriving someone of their life, while in the Albanian Customary Law, violation of honor was inexcusable, and would lead to the death of the perpetrator to redeem honor (Article 598). This phenomenon in Islamic law is thought to come from pre-Islamic traditions applied by Arabs. ${ }^{31}$

\subsubsection{Protection}

Different from the truce, which is achieved through an agreement between the requestor and requestee of the truce, protection is given unilaterally. So, an endangered person is put under the protection of an individual without the consent of the person who threatens him with physical harm. ${ }^{32}$ Thus, if a person under staying at a host's house was killed, the perpetrator would be in a blood feud the family where the victim

28 Ismet Elezi, E Drejta Zakonore e Labërisë (Tiranë: Toena; 2002), 33.

29 Ulqini, Struktura e Shoqërisë Tradicionale Shqiptare, 108.

30 Ahmeti, Kur'an-i - Përkthim me Komentim në Gjuhen Shqipe, 146.

31 Ayfer Yazgan, Morde ohne Ehre: der Ehrenmord in der modernen Türkei; Erklärungsansätze und Gegenstrategien, (Kultur und soziale Praxis), (Bielefeld: transcript Verlag, 2010), 53.

32 Ismajli, Besa në të Drejtën Zakonore Shqiptare, 100. 
was sheltered. ${ }^{33}$

According to the KLD, the biggest privilege of a guest was protection (nora or menorja). This institution sanctioned the protected status of the guest while was eating from the host's table. ${ }^{34}$ Further, if a person crossed paths with an enemy, it would be enough to say: "I am eating a host's bread." or "I am under the protection of the host." and it would save his life and allow him to pass. If the guest was killed under the protection of a host, the host had to seek vengeance under any circumstance. Killings under protection included:

- the murder under the protection of an individual or village;

- the murder of a servant (herder) under the protection of an individual;

- the murder of a mediator under the protection of an individual;

- the murder of a craftsman under the protection of the village;

- the murder of a priest or imam under the protection of the village;

- the murder of a foreigner under the protection of the village.

\subsection{Negative aspects}

\subsubsection{Vengeance and blood vengeance}

The Albanian dictionary of 1981 defines blood vengeance (in Albanian: gjakmarrja) as the following: "A savage and primitive tribal custom according to which, in order to avenge someone who was killed, a person from the family or clan of the perpetrator had to be killed." 35 Vengeance was considered the retaliatory punishment in exchange for a bad deed. Thus, the difference is that no blood was drawn when vengeance was applied. Yet, these terms should be used with care because there were cases when blood vengeance was invoked as a result of honor infringement, and were not related to previous killings. Further, the aim of blood vengeance was to control or limit the number of killings lest huge chaos was caused. ${ }^{36}$ According to Elezi, blood vengeance killings have origins in antiquity as a result of a close-knit life and protection, considering there was no state to defend the lives of the people. ${ }^{37}$

Blood vengeance and feuds, as archaic phenomena of customary law, were also applied by other communities. For example, Article 196 of the Code of Hammurabi $i^{38}$ from 1750 B.C. wrote "If a man destroys the eye of another man, they shall destroy his eye." While physical punishments (lashes), maiming (breaking of bones) and injuries to bodily organs (Articles 195, 197, 218, 226, 235, 192, 205, 2282) were stipulated in the Code of Hammurabi, the Albanian customary law did not include such punishment. Blood vengeance in Ancient Athens was a very common phenomenon.

33 Hilmi Ismajli, “Ndorja ose Ofrimi i Mbrojtjes në të Drejten Zakonore Shqiptare”, Prishtinë, "Përmbledhje Punimesh", Fakulteti Juridik, (1978), 159.

34 KLD, Article 653 stipulates: "The guest occupies the place of honor at the table, and is thereupon under the protection of the house."

35 Androkli Kostallari, Fjalori i Gjuhës Shqipe, (Prishtinë: Rilindja, 1981), 597.

36 Hasluck, The Unwritten Law in Albania, 22-23.

37 Ismet Elezi, Vrasjet për Hakmarrje e Gjakmarrje në Shqipëri, (Tiranë Qendra Shqiptare për të Drejtat e Njeriut, 2000), 11.

38 Hilmi Ismajli, Burime te Zgjedhura Juridike Historike I, (Prishtinë: Fakulteti Juridik 2001). 
This phenomenon was limited by the Draconian constitution. ${ }^{39}$ Ever since this code was put in place, vengeance and blood vengeance were not considered private issues anymore, but the state intervened to deliver capital punishment of death. Physical punishments, maiming and beatings were not applied.

It was said among the Germans that "the violation of family and tribal honor by outsiders would be solved with blood vengeance." 40 Among the Germans, blood vengeance was not only limited to blood relation, but it was also an obligation of friends. ${ }^{41}$ Such phenomena were passed on until the $9^{\text {th }}$ century when the manner of vengeance changed. In this period of time, known as the Frankish period, the leges Barbarorum started being used. A system of fines was applied called Wergeld or Manngeld for victims or damaged parties in case of these killings. This fine was known as compensatio in Roman law and was equal to one herd of livestock. ${ }^{42}$ The same system of compensation in money or livestock for a murdered person among Albanians was called dieta and was applied in the Kanun of Labëria in Southern Albania. This method considered fairer than blood vengeance, taking into account the family needs of the victims. ${ }^{43}$

According to Islamic law based on the Quran, vengeance and blood vengeance were recognized. First, there were attempts to find a solution through payments in money or camels (livestock). In case an agreement between the subject of the crime and the sufferer was not achieved, the eye for an eye, tooth for a tooth principle was applied. ${ }^{44}$ According to this Islamic law, bodily punishments were applied, such as lashing, stoning, severing of hands, ${ }^{45}$ whereas the KLD did not include such punishments. According to the Encyclopedia of Yugoslavia, ${ }^{46}$ blood vengeance was applied among South Slavs, too. In Montenegro it was applied up to the first half of the $20^{\text {th }}$ century, in Croatia (Dalmatia) up to the $18^{\text {th }}$ century, and in Bosnia and Herzegovina and Serbia up to the $19^{\text {th }}$ century. Blood vengeance was also applied in Corsica, southern Italy, Turkey and among other peoples. In Afghanistan, according to the customary law of the predominant Pashtuns, blood feuds can be solved through

39 Hilmi Ismaili and Fatmir Sejdiu, Historia e Institucioneve Shtetërore dhe Juridike, (Prishtinë: Fakulteti Juridik, 2017), 92.

40 Hinrich Rüping and Günter Jerouschek, Grundriss der Strafrechtsgeschichte, Vol. 6. (München: Beck Verlag, 2011), 3.

41 Rainer Schröder, Rechtsgeschichte, Vol. 9 (Münster: Alpmann Schmidt Verlag, 2013), 24, taken from the original Tacitus: Germania, in: Die Historischen Versuche, Vol 2., translated Büchner, Karl, (Stuttgart: Kröner, 1963), 149-173.

42 Rüping and Jerouschek, Grundriss der Strafrechtsgeschichte, 4.

43 Nova, Koço, "Dhënia e Drejtësise sipas së Drejtës sonë Zakonore", "Etnografia Shqiptare dhe disa probleme te saj (Tirana: 'Konfereca Kombetare e Studimeve Etnografike, No. 16), (Tiranë: Akademia e Shkencave e RPS të Shqipërisë, 1989), 163.

44 Marit Cremer, Angekommen und integriert? Bewältigungsstrategien im Migrationsprozess, (Berlin: Freie Universität Berlin, Disertation 2016), (Frankfurt/New York: Campus Verlag, 2017), 33.

45 Bruno Schoch, Reinhard Mutz and Friedhelm Solms, Friedensgutachten 1996, (Münster: LIT, 1996.), 73.

46 Enciklopedija Jugoslavije, tom. V, (Zagreb: Leksikografski zavod FNRJ, 1956.), (Krvna osveta). 
forgiveness, or if the perpetrator offers two girls of marriage age to the family of the victim. ${ }^{47}$ Blood vengeance also finds application in South African communities and other countries.

According to the Albanian customary law, blood vengeance means the killing of an individual to avenge a person killed in the past. The KLD initially stipulated personal responsibility for the perpetrator. This Kanun prohibited killing in return for crimes (Article 909 of the KLD). It determines: "The penalty for any crime committed by one Albanian against another Albanian may be adjudicated by Elders and by means of pledges, but bloodshed is not permitted, since a crime may not be recompensed with blood." In addition, Article 912 of the KLD includes: "If someone comes to rob me, even if I see him opening the door and I kill him, I incur his blood" contrary to Article 914 which determines: "If someone threatens you or beats you and you kill him, you incur the blood feud."

Thus, according to the KLD, every action that is to do with murder needs to be proportional to the act committed by the perpetrator. Blood vengeance in the KLD was allowed against the person who committed the killing or injury. ${ }^{48}$ Article 898 of the KLD determines that: "Blood follows the finger" (fathers shall not be killed in place of their sons, nor sons in place of their fathers, but each shall die for his own sin) and "blood is paid for with blood". Furthermore, Article 899 prohibits the killing of the perpetrator's family members. Women were excluded from blood feuds. In this context, Article 897 has foreseen: "The family of the victim may not take vengeance on the women of the murderer's family because a woman and a priest do not incur the blood feud." Also, Article 835 includes: "An ambusher must fire his gun at men, and not at women, children, a house, or livestock." It is important to mention the rule that within 24 hours of the murder or injury, the family of the victim had the right to incur the blood feud on a broader circle of male family members (Article 900 of the KLD). That is the reason why Articles 870 and 871 of the KLD provided that these individuals would isolate themselves. If it happened that after 24 hours the family of the victim drew blood in the perpetrators extended family, according to Article 873 of the KLD he did not avenge the blood, but incurred blood. However, this law was not always strict (cogens) and incurring blood was allowed against men who lived in a home (father, son, brother, etc.). In the Mirdita variant of KLD, Article 212 states that "a maternal uncle can avenge the blood of his nephew, and the nephew can avenge his maternal uncle's blood." However, Article 700 defines relationships stemming from the side of the father as The Tree of Blood (within which blood feuds happen) and Article 701 defines relatives on the mother's side as The Tree of Milk.

In cases of suicide, the object of the victim and the method may show whether incurring blood is allowed. For instance, if two men were left dead after a conflict between them, Article 901 sets out that neither of them are to be avenged. According to Article 958, if somebody kills himself, "his blood remains unavenged". If a man

47 Lars Wienand, "Asylbescheid: Afghane kann mit Frauen Blutschuld begleichen ", 06.07.2018. Available at: https://www.tonline.de/nachrichten/deutschland/gesellschaft/id_84071700/bamfbescheid-afghane-kann-mitmaedchen-blutschuld-zahlen.html 
kills his brother, a fine must be paid (Article 960 of the KLD) but if a son kills his father, the perpetrator is executed either by the clan or by the village. When a son killed his mother, then he would incur blood feud with the father of the woman, whereas if a wife killed his husband, then the father of woman would incur blood feud with the family of the husband (Articles 963 and 964 of the KLD). Blood feuds have caused the deaths of many people, but women were never affected. However, according to Article 920: "If two people are caught together committing adultery and are killed, their blood remains unavenged." The KLD allows killing to avenge violated hospitality, weapons and adultery (Article 922 of the KLD) and treason. If death was caused because of carelessness, Article 932 states that: "Involuntary manslaughter is not avenged by the gun. The murderer pays for the blood and guarantees are given" Another important characteristic of the KLD is that statute of limitations for murders were not known. This allowed blood to be avenged 100 or 200 years after the first killing. Also, killings would continue to happen as one blood vengeance would not resolve the conflict.

\subsubsection{Suspension and prohibition of blood vengeance}

A rule in the Kanun suspended blood vengeance when the perpetrator was with his wife or children. For wives, children and livestock, the Kanun stipulated protection: "If an ambusher fires at women, children, a house or livestock, he violates the Kanun..." (Article 836 of the KLD). Killing was not allowed in retaliation to robbery or insults. Thus, Article 910 of the KLD defines: "If someone abuses me and I kill him, I incur blood."

\subsubsection{Gender inequality}

In Articles 891-893 of the KLD, the protection of all human life is guaranteed, regardless of gender and age. The physical and medical condition of were also irrelevant to the Kanun. Human life is also protected according to Article 212 of the KLD, the Mirdita Variant stating "do not kill or you will be killed".

The KLD also set out other norms that guaranteed the respect and inviolability of the basic rights and freedoms of people (men) through Article 593 (as well as Article 594 partially) where was stated: "The Kanun does not make any distinction between man and man"; "Soul for soul, all are equal before God"; "A handsome man may be engendered by an ugly one, and an ugly man by a handsome one; and "On his own scale, each man weighs the same as everyone else." Yet, these principles did not apply to women. Thus, subchapter 28 specifies that "the blood of a woman is not equal to the blood of a man".

The KLD concept for gender inequality of the women is summarized in subchapters 28 and 29. The KLD was applied in places when urban Albanian society in the Middle Ages was set in order by civil statutes (of Shkodra, Durrës, Drisht, Ulqin etc.). Islamic law (Sharia) stipulated punishments against women, which were not known in the Albanian customary law. Sharia law sanctioned women's dress, they 
were lashed, in cases of adultery they were stoned, and their limbs were also cut off. ${ }^{49}$

\subsubsection{The right to marriage according to the KLD}

Article 28 of the KLD defines marriage as an institution "to form a household, adding another family to the household, for the purpose of adding to the work force and increasing the number of children." According to Article 30 of the KLD, the son did not have the right to concern himself with his own marriage, unless his parents were deceased. Women were not allowed to have a say in their marriage regardless of whether her parents were alive. Her fate would fall in the hands of her brothers or cousins. If the woman refused to marry the man assigned to her, and her father supported her daughter, she was not allowed to marry anybody else as long as the assigned husband is alive (Article 43 of the KLD). Widowed women were allowed to choose their husbands themselves (Article 36 of the KLD).

It is important to mention the crucial difference between marriage within family law between the Albanian customary law and Islamic Sharia law. Ottoman family law, which was applied during the approximately 500 years of Ottoman rule in Albanian territories, had its basis in Sharia law, was first codified in the Islamic world through the Law on Family on October 1917 in Turkey. ${ }^{50}$ This law was applied in occupied Albanian lands. However, while according to Islamic law marriage within the family were allowed (with cousins, excluding mothers, daughters, sisters, paternal aunts, maternal aunts, nieces, Surah 23:4 of the Quran), ${ }^{51}$ such marriages were not allowed in the Albanian customary law, "even if the family of an Albanian is divided into four hundred branches..." (Article 697 of the KLD). This fact is testament to the authenticity of the Albanian customary law and the lack of influence by the aforementioned law.

Laws regarding marriage and wedded life in the Albanian Kanun were also patriarchal. Sons and daughters were not allowed to decide about their respective marriages while their parents were alive. In Islamic law, girls needed to give their consent for marrying; this right was recognized for the first offer she received from a man, but afterwards she was obligated to choose one of her cousins. ${ }^{52}$ While according to Islamic law, men were allowed to marry up to four women (Surah 4:3 of the Quran), ${ }^{53}$ marriage in the Albanian customary law was mostly monogamous (the Catholic Church prohibits bigamy). According to the Albanian customary law, a man would take another woman, keeping her in the house with the same rights, in case he was unable to conceive males with the first wife. ${ }^{54}$ Sharia law prohibited Muslim women from marrying men of other religions unless they converted to Islam (Surah 221:2), ${ }^{55}$ whereas the Albanian customary law did not prohibit such marriages.

49 Christine Schirmacher, Die Scharia. Recht und Gesetz im Islam, (Holzgerlingen: SCM-Verlag, 2015), 32 .

50 The Ottoman Family Law was abrogated with the establishment of the Republic of Turkey in 1926, which was based of Swiss Family Code.

51 Ahmeti, Kur'an-i - Përkthim me Komentim në Gjuhen Shqipe, 113-114.

52 Schirmacher, Die Scharia. Recht und Gesetz im Islam, 46.

53 Ahmeti, Kur'an-i - Përkthim me Komentim në Gjuhen Shqipe, 109.

54 S. G. D., Zakonet e Rekës së Gjakovës, in: "Populli”, No. 32, (April 1915), 3.

55 Ahmeti, Kur'an-i - Përkthim me Komentim në Gjuhen Shqipe, 64. 
Thus, according to the Albanian customary law marriages were allowed with few exceptions, not only between Christian Albanians, but also with Muslim Albanians until the second half of the $19^{\text {th }}$ century. ${ }^{56}$ So, the new faith of Islam did not break this bond between Albanians. Intermarrying allowed Albanians to preserve good cooperation, general resistance against assimilatory influences of religious ideologies.

According to the Quran, if a man and a woman had extramarital sexual relations, they would receive 100 lashes, and if the woman was married she would be stoned (Surah 24:2). ${ }^{57}$ According to the Albanian customary law, these cases were considered a violation of the man's honor (Article 601 of the KLD), and also the women's family's honor. Thus, this act brought heavy consequences for the family of the perpetrator. If people were caught adulterating, they could be killed with one bullet. This bullet would be given to the husband by the father of the bride on the day of the wedding, so that the husband could use it in case the wife was caught in the act of adultery. Neither the man nor the woman killed would incur blood. It is important to underline that according to the Quran (Surah 24:4), somebody who accused a woman of being chaste and failed to bring forth four witnesses, the accuser would receive 80 lashes and his testimony would never be accepted afterwards.$^{58}$ Unfortunately, these archaic and patriarchal phenomena of the KLD continue to have importance in the lives of Albanians today, especially regarding the social exclusion of women. ${ }^{59}$ There are many cases where families were the deciding factors in breaking up marriages and creating conflicts with other families, because the KLD also has punishments for men who marry women without the consent of the bride's parents; the family of the man, or the man himself, if the family did not take responsibility, would incur blood with the family of the woman. However, influences from other cultures nowadays are bringing about positive changes in younger generations. ${ }^{60}$

\subsubsection{The exclusion of women from the right to inheritance}

Subchapter 20 of the KLD sets out that Albanian women are entirely excluded from inheritance in her own and her husband's families. According to Subchapters 28-32 of the KLD, it is stipulated that "The wife who is left, in leaving her husband's house, has not the right to take anything with her except the clothes she is wearing." Article 88 determines that "The Kanun recognizes the Son as an heir, but not the daughter." and Article 91 excluded women from entitlement to inheritance by her parents or husband. Article 91 includes "If the male line of the house dies out, even

56 Kahreman Ulqini, „E Drejta Kanunore Shqiptare përball së Drejtës Kanonike dhe Sheriatit“, in:"Etnografia Shqiptare”, No 16, Tiranë: Akademia e Shkencave e RPS të Shqipërisë, (1989), $72-77$.

57 Ahmeti, Kur'an-i - Përkthim me Komentim në Gjuhen Shqipe, 402.

58 Ahmeti, Kur'an-i - Përkthim me Komentim në Gjuhen Shqipe, 402.

59 Hermine De Soto, Peter Gordon, Ilir Gëdeshi and Zamira Sinoimeri, Poverty in Albania. A Qualitative Assessment, (Washington: World Bank Technical Paper; No. 520., (May 2002), 89, 99, 117.

60 Angjelina Hamza, "Martesa në Kulturën Shqiptare Dikur dhe Sot”, in: "Kumtesat e Shkencat Gjuhësore, Kulturore dhe Historike" - "Java e Shkencës", Prishtinë: Ministria e Arsimit, e Shkencës dhe e Teknologjisë Departamenti i Shkencës dhe i Teknologjisë (2013), 41. 
though there may be a hundred daughters, none of them have the right to any share in the inheritance of their parents, nor do any of their sons or daughters".

Article 108 of the KLD sets out that a father cannot bequeath real property or wealth to his daughters, even if he does not have a son. Whereas according to Article 109, a father may give his daughters money, goods and chattels, yet were not allowed to demand gifts promised by their father during his lifetime after he died. Article 114 writes "If a man who dies without direct heirs has married daughters, the cousins who assume possession of his property are obliged to receive and accompany them, according to the law." As a compensation for the inheritance, cousins would provide care to the daughters, receive and accompany them, and arrange wakes if any of the girls dies in his house before or after marriage (Articles 99-102 of the KLD). For instance, in Islamic law, women were entitled to inheritance from their parents and their husband's families, yet less so than men. ${ }^{61}$ This difference also showcases the originality of the Albanian customary law.

\section{CONCLUSION}

Albanian customary law is an authentic body of customary law that originated in ancient times. It is contained in different sources called Kanuns, which apply to particular territories. Yet, it is important to consider that in the European Renaissance, no people achieved something by itself. That which was left unfinished by one, was completed by the other. Through this we reinforce the thesis of author Koço ${ }^{62}$ who stated that the Albanian customary law, in some places more than others, influenced other customary laws, elements and institutions, which were applied in Albanian territories. Terms and institutions such as zakon, kapetan, vojvodë, porotë, poronik, kapucar, gjobë, bajraktar were borrowed into the Albanian customary law, whereas the word besa was transferred to other cultures. This means that in some places there was a culture of creation, and in others the culture of reception of law.

The essential difference between the Albanian customary law and the customary law of other European countries is that the latter transformed and codified customary law into state law, whereas the Albanian customary law was never codified into state law. Another difference is that the Albanian customary law was applied since antiquity until the $20^{\text {th }}$ century (and in some segments even today) whereas European customary laws were applied in shorter time frames. Unlike other bodies of customary law, which had characteristics of state laws, the Albanian customary law throughout its history of application did not receive this attribute (excluding the feudal period in antiquity), which would be collected, codified and sanctioned by specific state organs. Another characteristic is that, according to many Council of Europe progress reports, the application of some institutions of the Albanian customary law, especially the KLD, continues to be present in contemporary times. These archaic institutions, such as vengeance and blood vengeance, are especially prevalent in northern Albania. Such a phenomenon is not present in Kosovo according to the same European institution.

61 Ahmeti, Kur'an-i - Përkthim me Komentim në Gjuhen Shqipe, 110-111.

62 Novo Koço, Dhënia e Drejtësisë sipas së Drejtës sonë Zakonore, 105. 


\section{BIBLIOGRAPHY}

1. Ahmeti, H. Sherif. Kur'an-i - Përkthim me Komentim në Gjuhen Shqipe: Prishtinë: Kryesia e Bashkësisë Islame për RS të Serbisë, 1988.

2. Çabej, Ekrem. Zakone dhe Doke të Shqiptarëve, në: "Studime Shqiptare", vëll. V. Prishtinë: Rilindja, 1976.

3. Cremer, Marit. Angekommen und integriert? Bewältigungsstrategien im Migrationsprozess (dissertation). Frankfurt/New York: Campus Verlag. 2017.

4. De Soto, Hermine, Peter Gordon, Ilir Gëdeshi, Zamira Sinoimeri. Poverty in Albania. A Qualitative Assessment. Worlg Bank Tehnical Paper No. 520. Washington: The World Bank Washington D.C., May 2002.

5. Doucette, R. Serge, Hamdi Thaqi. Kosova "Demokraci Morale" apo Kosova "Serbi e Madhe". Prishtinë: Europrinty, 2004.

6. Dragovaja, Muharrem. Studim Krahasues i Kanunit te Shqipërise dhe Dagestanit. Tiranë: University of Wisconsin - Madison, 1996.

7. Elezi, Ismet. E Drejta Zakonore e Labërisë. Tiranë: Toena, 2002.

8. Elezi, Ismet. Vrasjet për Hakmarrje e Gjakmarrje në Shqipëri. Tiranë: Qendra Shqiptare për të Drejtat e Njeriut, 2000.

9. Enciklopedija Jugoslavije, tom. V. (Krvna osveta). Zagreb: Leksikografski zavod FNRJ, 1956.

10. European Commission, Commission Staff Working Document Albania 2016 Report, Brussels, 9 November 2016. Accessed on 13. July 2019, https://ec.europa.eu/ neighbourhoodenlargement/sites/near/files/pdf/key_documents/2016/20161109_report albania.pdf.

11. Fletorja Zyrtare e Republikës së Shqipërisë. Tiranë: Botim i Qendrës së Botimeve Zyrtare. 2015 - Nr: 38.

12. Frashëri, Sami. Shqipëria ç'ka qenë, ç'është e ç'do të bëhet. Prishtinë: Dija, 2007.

13. Gjeçovi, Shtjefën. Kanuni Lekë Dukagjinit. Shkoder: Independent Publishing Platform, 2014.

14. Gjoni, Mariglena. Ndikimi i Fenomenit të Gjakmarrjes në Vetëkonceptin e Fëmijëve të Moshës 7-15 vjeç (dissertation). University of Tirana: The Department of PsychologyPedagogy, Faculty of Social Sciences, 2016.

15. Hamza, Angjelina. "Martesa në Kulturën Shqiptare Dikur dhe Sot". In: Kumtesat I, Shkencat Gjuhësore, Kulturore dhe Historike, "Java e Shkencës". Prishtine: Ministria e Arsimit, e Shkencës dhe e Teknologjisë Departamenti i Shkencës dhe i Teknologjisë (2013): 37-41.

16. Hasluck, Margaret. Kanuni Shqiptar: Ligji i Pashkruar Shqiptar. Translated from English by Leka Ndoja. Tiranë: Lisitan, 2005.

17. Ismajli, Hilmi. Besa në të Drejtën Zakonore Shqiptare, Gjurmime Albanologjike Nr. 1. Gjurmime Albanologjike - Folklor dhe etnologji. Vëll. I. Prishtinë: Instituti Albanologjik i Prishtinës, 1971.

18. Ismajli, Hilmi. Burime te Zgjedhura Juridike Historike I, Prishtinë: Fakulteti Juridik, 2001.

19. Ismajli, Hilmi. Ndorja ose Ofrimi i Mbrojtjes në të Drejten Zakonore Shqiptare. Në: "Permbledhje punimesh". Prishtine: Fakulteti Juridik, 1978.

20. Ismaili Hilmi and Fatmir Sejdiu. Historia e Institucioneve Shtetërore dhe Juridike. Prishtinë: Fakulteti Juridik, 2017.

21. Kikia, Mentor. The leader of the organization Free Thought Forum: Interview for Radio Evropa e Lirë (14.01.2014).

22. Koço Nova. "Dhënia e Drejtësise sipas së Drejtës sonë Zakonore". Etnografia Shqiptare dhe disa probleme te saj. Tirana: 'Konfereca Kombetare e Studimeve Etnografike, No. 16. Tiranë: Akademia e Shkencave e RPS të Shqipërisë, 1989: 83-109. 
23. Koliqi, Ernest. E Drejta e Kanunit Shqiptar dhe e Drejta Romake. In "Studime e Tekste Juridike", Nr. I, Romë: Botim i Insitutit të Studimeve Shqiptare, 1944.

24. Komisioni Evropian, Dokument Pune i Personelit të Komisionit Raport për Kosovën, 2018, Strasburg, 17.4.2018SWD (2018) 156 final. Accesable on 13. July 2019. https:// www.m-ks.net/repository/docs/kosovo_report_2018_shqip.pdf

25. Komisioni Evropian, Dokument Pune i Stafit të Komisionit - Raporti i Vitit 2015 për Shqipërinë, Bruksel 10.11.2015 DPS (2015). Accessed on 13. July 2019. https://amf.gov. al/files2/File/Komisioni\%20Evropian,\%20raporti\%20i\%20vitit\%202015\%20per\%20 Shqiperine.pdf.

26. Kostallari, Androkli. Fjalori i Gjuhës Shqipe. Prishtinë: Rilindja, 1981.

27. Lawson Colin W., Douglas K. Saltmarshe. "The Psychology of Economic Transformation: The Impact of the Market on Social Institutions, Status and Values in a Northern Albanian Village". Journal of Economic Psychology, vol. 23/4, (2002): 487-500.

28. Lelçaj Lulzim, Zef Mila, Rajmonda Kçira, Konfliktet dhe Zgjidhja e Tyre: Material Shpjegues dhe Orientues: Conflicts and their Resolution: An Explanatory, Orienting Material, Shkoder: Qendra "Drejtesi dhe paqe", 2001.

29. Malcolm, Noel. Kosovo a Short History. New York: University Press, 1999.

30. Myftiu, Genc. Albania a Patrimony of European Values: A Short Encyclopedia of Albanian History and Cultural Heritage. Tiranë: SEDA Agency: FILD Fondation, 2000.

31. Origuchi, Shinobu - Zenshu. Obras Completas de Origuchi Shinobu. Tokyo: Chüo Koronsha, (1954): 3-62.

32. Peinsipp, Walther. Populli i Shqipeve të Malit. Tiranë: Shtëpia botuese "Mirdita", 2005.

33. Pupovci, Syrja. Marrëdheniet Juridike - Civile në Kanunin e Lekë Dukagjinit. Prishtinë: Enti TMM, 1971.

34. Qana, Natalja. Qasje Socialo-Historike e Fenomenit të Gjakmarrjes dhe Pasojave të tij mbi Gratë dhe Fëmijët (dissertation). University of Tirana, The Institute of International Studies, 2016.

35. Rüping, Hinrisch and Günter Jerouschek. Grundriss der Strafrechtsgeschichte, Vol. 6. München: Beck Verlag, 2011.

36. S. G. D. Zakonet e Rekës së Gjakovës. "Populli”, Nr. 32, 3 Prill 1915.

37. Schirmacher, Christine. Die Scharia. Recht und Gesetz im Islam. Holzgerlingen: SCMVerlag, 2015.

38. Schoch, Bruno, Reinhard Mutz, Friedhelm, Solms. Friedensgutachten 1996. Münster: LIT, 1996.

39. Schröder, Rainer. Rechtsgeschichte. Münster: Alpmann Schmidt Verlag, 2013.

40. Spahia Emin. Të Zhdukim Ngujimin Kolektiv dhe të Respektojmë Shtetin Ligjor, We should Strike Out the Collective Fastening and Respect the Legal State. Ligji dhe Jeta, UNFPA 2003.

41. Ulqini, Kahreman. "E Drejta Kanunore Shqiptare përball së Drejtës Kanonike dhe Sheriatit”, Etnografia Shqiptare, Nr. 16, Tiranë, (1989): 65-81.

42. Ulqini, Kahreman. Struktura Shoqërisë Tradicionale Shqiptare. Shkodër: Idromeno, 2003.

43. Wienand, Lars, Asylbescheid: Afghane kann mit Frauen Blutschuld begleichen, 06.07.2018. Accesable on 13. July 2019. https://www.tonline.de/nachrichten/deutschland/ gesellschaft/id_84071700/bamf-bescheid-afghane-kann-mitmaedchen-blutschuldzahlen.html

44. Yazgan, Ayfer. Morde ohne Ehre: der Ehrenmord in der modernen Türkei: Erklärungsansätze und Gegenstrategien (Kultur und soziale Praxis). Bielefeld: Transcript Verlag, 2010. 


\section{Islam Qerimi*}

Sažetak

\section{POSEBNI PRAVNI INSTITUTI KANUNA LEKË DUKAGJINA I NJIHOVA PRIMJENA MEĐU ALBANCIMA U SUVREMENO DOBA}

Svrha je ovog rada rasprava o primjeni nekih posebnih pravnih instituta Kanuna Lekë Dukagjina u suvremenom albanskom pravu. Tradicionalno, ovaj Kanun imao je, i još uvijek ima, utjecaj na svim područjima života Albanaca. Drugim riječima, primjena Kanuna još je izazov suvremenom pravnom sustavu jer narod nastavlja rješavati svoje prijepore temeljem Kanuna. Cilj ovog rada je objasniti pisano običajno pravo, istaknuti prednosti i mane njegove primjene kao i vezu s nekim pravilima javnog (kaznenog) i privatnog (građanskog) prava.

Ključne riječi: običajno pravo; Kanun Lekë Dukagjina; suvremeno pravo; pravo Kosova.

\section{Zusammenfassung}

\section{SONDERINSTITUTE DES KANUN VON LEKË DUKAGJINI UND SEINE ANWENDUNG IM ZEITGENÖSSISCHEN ALBANIENS}

Der Schwerpunkt dieses Beitrags liegt auf der Anwendung von gewissen Sonderinstituten wie Kanun von Lekë Dukagjini im zeitgenössischen Recht Albaniens. Traditionell habe das Institut auf alle Lebensbereiche der Albaner bis heute Einfluss ausgeübt. Mit anderen Worten, fordert seine Anwendung das moderne Rechtssystem heraus, weil sich die Leute weiterhin stark auf Kanun verlassen um ihre Missverständnisse aus dem Weg zu räumen. Es wird daher auf geschriebenes Gewohnheitsrecht, sowie auf Vorteile und Nachteile seiner Anwendung in Verbindung zu einigen Bestimmungen vom öffentlichen (Straf)Recht und privatem (Zivil)Recht hingewiesen.

Schlüsselwörter: Gewohnheitsrecht; Kanun von Lekë Dukagjini; zeitgenössisches Recht; Kosovorecht.

* Dr. sc. Islam Qerimi, docent, Sveučilište „Isa Boletini” u Mitrovici, Pravni fakultet; islam. qerimi@umib.net. 
Riassunto

\section{ISTITUTO SPECIALE DEL KANUN DI LEKË DUKAGJINI E LA SUA APPLICAZIONE NELL'EPOCA CONTEMPORANEA DEGLI ALBANESI}

Lo scopo di questo articolo è di discutere l'applicazione di alcuni istituti speciali del Kanun di Lekë Dukagjini nell'epoca contemporanea degli albanesi. Tradizionalmente, questo kanun ebbe ed ancor oggi ha impatto in ogni campo della vita degli albanesi. In altre parole, l'applicazione di questo kanun sfida ancora il sistema giuridico moderno come una conseguenza del fatto che la gente continua a risolvere i propri malintesi basandosi sul kanun. Attraverso questo articolo si mira a fare chiarezza sul diritto consuetudinario scritto ed a evidenziare i vantaggi e gli svantaggi della sua applicazione e del collegamento con alcune regole del diritto (penale) pubblico e del diritto (civile) privato.

Parole chiave: diritto consuetudinario; Kanun di Lekë Dukagjini; diritto contemporaneo; diritto del Kosovo. 